\title{
PARTNERS IN CRIME: \\ PENTECOSTALISM AND BOTSWANA \\ HIVIAIDS POLICY ON CROSS-BORDER MIGRANTS
}

\author{
Dr Rosinah Mmannana Gabaitse \\ University of Botswana \\ rosegabaitse@yahoo.com/gabaitser@mopipi.ub.bw
}

\section{ABSTRACT}

In this paper I seek to interrogate how the theology of some Pentecostal churches, especially the theology that God heals HIV and AIDS, interacts with the situation of cross-border migrants in Botswana. I also seek to discuss the Botswana HIV policy which denies HIV-positive cross-border migrants access to Anti-Retroviral treatment (henceforth ARVs) which has proven to prolong and improve the quality of life of people living with HIV. Conflict exists between Botswana HIV policy on strict adherence to ARVs and some Pentecostal churches' insistence that members of their churches living with HIV are healed by God, and therefore they should not take ARVs. While the Pentecostal Church is a 'home away from home' for migrants, their theology is in constant conflict and clashes with Botswana HIV health policy, even if the reality is that the same policy denies migrants access to HIV services. It is ironic that both the HIV policy and the Pentecostal theology are in pursuit of preserving life; yet, they both deny cross-border migrants that very life.

Keywords: HIVIAIDS; Anti-Retrovirals; Botswana; Pentecostal churches; crossborder migrants.

\section{Introduction}

In the past 20-30 years sub-Saharan African countries such as Botswana, Zimbabwe, South Africa and Swaziland have experienced the rapid increase of HIV infections,

\section{UNISA}

Studia Historiae Ecclesiasticae Volume 41 | Number 1 | 2015 pp. 20-39
DOI: http://dx.doi.org/10.17159/2412-4265 /2015/v41n1a3 Print ISSN 1017-0499 | Online 2374-3689 (C) 2015. Studia Historiae Ecclesiasticae 
often resulting in death due to opportunistic infections. While the HIV infection rates were going up, countries such as Zimbabwe and Somalia were going through political instability. This crisis saw many Zimbabweans and Somalis fleeing into Botswana and neighbouring countries, such as South Africa, for better living conditions. ${ }^{1}$ Considering that HIV prevalence rates in Africa have always been high, it is highly likely that some of these migrants came to Botswana to access ARVs, which means they were already infected with HIV and some got infected during their stay in Botswana. ${ }^{2}$ Although it is well known that people living with HIV (who have a low CD4 count) need ARVs to stay alive, it is unfortunate that the Botswana HIV policy denies migrants living with HIV, accessibility to ARVs and HIV services such as testing within government hospitals and clinics. The non-availability of ARVs throws cross-border migrants into a situation of hopelessness, as they face the possibility of death in a foreign land. This is unfortunate because Botswana is said to have 'migrant friendly legislation on the books'. ${ }^{3}$ The increase of migrants in Botswana and the high rates of HIV/AIDS in sub-Saharan Africa coincided with the exponential growth of Pentecostal churches globally. Botswana Pentecostalism expanded as Pentecostalism was growing globally; and this expansion was largely due to migration of different Africans into Botswana. Research indicates that Pentecostal churches globally and in Africa have become homes for migrants and the same is true for Botswana Pentecostalism. ${ }^{4}$ While the Pentecostal churches are mushrooming rapidly in Botswana, some theologies of some Pentecostal churches, for example that God heals HIV and the teaching of non-adherence to ARVs, are controversial, especially in the context of Botswana where HIV infections are high. This theology is accompanied with an understanding of healing that claims that God is able to completely remove the virus from the person's body. This theology contradicts medical science research which submits that once a person is infected with the virus, he or she will live with it for the rest of their life. This theology is not only controversial; it is dangerous, because without medication people may die from HIV related complications.

In this article I argue that the above theology is dangerous. Further, I argue that the Botswana HIV policy on denying cross-border migrants access to HIV services, especially ARVs, should be understood within the human rights framework. Denying cross-border migrants ARVs infringes on their right to health and life. I conclude the paper by demonstrating that both the Pentecostal Church and the Botswana government exist in tensions and ambiguities. Although they think they offer different responses to HIV, the consequences of their responses are the same; they are both partners in violating migrants' dignity and right to health and life. I conclude by suggesting ways for both institutions to meaningfully address the HIV situation of migrants in Botswana, since they should be at the forefront of preserving life. 


\section{The growth of the Pentecostal churches}

Studies across the world indicate that the Pentecostal movement is growing exponentially. The past decades have witnessed a dramatic shift and transformation in the growth and shape of Christianity. The greatest numbers of Christians in the world are from the global South and an increasing number of people in the South are choosing a version of Christianity that is Pentecostal in its orientation. As such, Pentecostalism is becoming the dominant expression of Christianity. ${ }^{5}$ Evidence is mounting which suggests that globally Pentecostalism is not merely a phase in the history of Christianity, but a force that appears to be here to stay. ${ }^{6}$ Botswana has also experienced this explosive growth of Pentecostalism within the past 10-15 years. Pentecostalism is large in Botswana, as Pentecostal churches are seen and felt everywhere, in cities, towns and villages. Further, Pentecostal tendencies are infiltrating mainline churches in Botswana as they do within some other African countries. ${ }^{7}$ Above all, these tendencies are being beamed directly into the homes of people in Botswana through dedicated TV channels such as God's channel and Emmanuel TV, such that even those who are not bona fide Pentecostals watch these programmes. The influence of Pentecostalism is therefore not limited to the Pentecostal churches alone; it is a phenomenon whose influence is felt in schools, homes and youth groups.

Pentecostal scholars suggest that there are multiple reasons for the growth of Pentecostal movements in Africa and elsewhere. ${ }^{8}$ Hanciles (2009) points out that the worsening political and economic conditions of most African societies have accelerated the growth of Pentecostal movements. He argues that the Pentecostal growth is more visible during 'times of crises and social unrest'. ${ }^{9}$ Asamoah-Gyadu (2005) maintains that the attraction to Pentecostal churches 'lies in the experiential and expressive nature of the movement, particularly its ability to offer health and wellbeing in this life'. ${ }^{10}$ This article contends that these are the two main factors that have accelerated the growth of the Pentecostal movement; even in Botswana. Due to its strong economy, good governance and economic stability, Botswana has been attractive to migrants and asylum seekers. ${ }^{11}$ From the late 1990s Botswana experienced an increased number of African cross-border migrants, especially from Zimbabwe, as the country was going through an economic and political crisis. ${ }^{12}$ According to Chirongoma (2006), when Zimbabwe was going through political crisis, all systems had basically collapsed, including the health care system. ${ }^{13}$ Not only did Zimbabweans migrate to Botswana but other Africans from Mozambique, Angola, DRC and Somalia began to be noticeable on the streets of most towns and villages. They were also observed within the Pentecostal churches, which offered them what many perceive to be a 'home away from home'. Thus, Botswana Pentecostalism also expanded with the coming of foreign Pentecostal churches into the country, for example the Family of God Church and Forward in Faith International from Zimbabwe. It also expanded with the coming of Nigerian Pentecostal churches such 
as Christ Embassy and Winners Chapel. It can be argued that the worsening political, economic and social conditions in some African countries accelerated migration into Botswana and this in turn expanded the growth of the Pentecostal churches within the country. ${ }^{14}$ Apart from those churches introduced from foreign countries, some of the migrants formed new Pentecostal churches, for example, Bible Life Ministries. ${ }^{15}$ Other migrants became members of existing churches such as the Apostolic Faith Mission and Assemblies of God. But what role, purpose and effect does migration have on cross-border migrants?

\section{Migration}

Migration happens for different reasons, purposes and motives, and it affects people of different races, nationalities, ages, as well as men and women belonging to different religions. People migrate voluntarily to seek better economic, educational and income-generating opportunities. Migration can be short term for those visiting family and friends or those establishing new churches. It can also be permanent for those seeking naturalisation and entering marriages with locals. It can also be seasonal, especially for migrants who engage in trade such as selling textile and other consumables not found in host countries. Migration can be forced or involuntary due to political and economic contexts of migrants' home countries. This migration takes place when people are faced with violence or threats of violence and well-being, thus leading to asylum seekers and refugees. In any country some migration is legal and the migrants are properly documented and authorised by immigration officials to stay and work within host countries. Others are illegal because they entered the country illegally or have overstayed in host countries. These are often undocumented by immigration officials. ${ }^{16}$ It can be argued that cross-border migrants fall within these different categories in Botswana as well. In this paper, the term cross-border migrants refers to a group of people who inhabit some space in Botswana but are not Batswana by birth or through naturalisation, no matter how long they have been in the country. The term cross-border migrants includes those fitting the categories of both forced and voluntary migrations.

Cross-border migrants form part of the marginalised, vulnerable, alienated and excluded groups everywhere in the world, even in highly industrialised countries. ${ }^{17}$ Often, the challenges that they face are many and varied. For instance, they are not entitled to the same economic and political rights and privileges that locals are entitled to. They are often viewed with suspicion and are unwanted by the dominant society. In some countries like South Africa, these suspicions have escalated into xenophobic attacks which resulted in the death of some African cross-border migrants in 2008 and recently in 2014. ${ }^{18}$ Many migrants are isolated and uprooted from their families, therefore they have less social and economic support. Some are in host countries without proper documents and therefore they are faced with threats of deportation. 
Although they may have proper documentation, some migrants are unskilled and they cannot find formal employment. Frequently their labour is exploited by the locals and they do not have a sustainable income. In Botswana the exclusion and marginalisation of cross-border migrants take different shapes and forms. One of the ways in which this marginalisation and exclusion are manifested, is through the entire healthcare system that denies cross-border migrants access to HIV education and especially HIV treatment. In such a context in Botswana, what role does the Pentecostal Church play in its HIV response for cross-border migrants?

\section{The Pentecostal Church: A home away from home?}

Pentecostal churches globally and in Africa have become homes for migrants. They offer stability, social support and protection to cross-border migrants in host countries. Writing within the European context, Ter Haar (1998) notes that Pentecostal churches help migrants to achieve a degree of security, especially in the face of the unfriendly immigration laws as a result of the reconstitution of the European Union. ${ }^{19}$ They pay attention to their fears, uncertainties and alienation as well as the general needs of migrants as they encounter life away from home, which is often characterised by different forms of marginalisation. ${ }^{20}$

The author has observed that Pentecostal churches in Botswana are home for many cross-border migrants; which is demonstrated in two major ways. ${ }^{21}$ First, most Botswana Pentecostal churches were founded and are led by cross-border migrants who are the leaders, pastors and prophets. Examples of such Pentecostal churches include: Deeper Life Ministries; New Seasons; Bible Life Ministries; Christ Embassy; Winners Chapel; Abundant Life; Revelation Times; and Holy Ghost Ministries. The migrants' pastors have created systems and rituals that are attractive to migrants living within Botswana, because they meaningfully address their needs. They have further developed a theology that is relevant to the experiences of migrants. Second, cross-border migrants are the face of most Pentecostal churches in Botswana because they dominate numerically within these churches. One of the possible reasons why migrants dominate numerically within Pentecostal churches is because they (Pentecostal churches) offer a space where migrants can celebrate their different cultures and identities. For instance, the author observed that the praise and worship team of Victory Fellowship, one of the Pentecostal churches in Botswana, is intentional about incorporating music from different countries during the Sunday church services. Migrants whose songs are sung not only enjoy hearing music in their vernacular, they are given the opportunity to introduce dance moves and rituals that accompany the songs. As such, Victory Fellowship is able to develop culturally relevant expressions; perhaps this is one of the reasons why it appeals to a wide spectrum of migrants from different countries. The celebration of different cultures symbolises the acceptance and embodiment of the different migrants from such cultures. It further symbolises the recognition of cross-border migrants as well 
as making them feel embraced. It can be argued that this demonstrates Pentecostals' ability to transcend cultural boundaries, as they give the members a sense of belonging, identity and well-being in a foreign country. The author, having been a cross-border migrant at some point, personally knows how comforting it is to be able to worship in a church where the pastor is familiar to pastors at home and to hear music or to see dance moves from home. It is not surprising that the many Pentecostal churches led by cross-border migrants in Botswana have an overwhelming membership of migrants, because these churches have systems and rituals that make sense to them.

The author further observed that within the Pentecostal spaces, believers are referred to as 'the sons and daughters of God'. No status can supersede this for a migrant who stays away from kith and kin. Thus, Pentecostal churches foster integration as migrants negotiate their marginality within the dominant society. The marginal status which migrants occupy, changes within the Pentecostal space as migrants discover brothers and sisters within the Pentecostal space. Further, their relationships are not just confined to church buildings; they exist even outside church grounds as members help each other to negotiate life in a foreign country. The relationships evoke solidarity and lead to the creation of a new community within the larger community. Social relationships are formed among migrants that offer spiritual, social, emotional and even financial support. ${ }^{22}$ Based on their shared experiences of being vulnerable and far away from their homes, cross-border migrants within the Pentecostal space identify themselves not as 'outsiders' but as fully human and fully affirmed. It can therefore be argued that the Pentecostal churches are making a significant contribution towards helping migrants navigate the new world that they inhabit. Pentecostalism is indeed a home away from home for cross-border migrants living in Botswana.

Although the Pentecostal movements positively embrace cross-border migrants and people on the margins as argued above, they also attract negative attention as they are viewed by some as 'controversial'. For example, in his studies on the Pentecostal and charismatic explosions in African countries, Gifford (1991, 1993) found Pentecostalism to be problematic, although the tone of his censure has been lowered somewhat in some of his recent publications. ${ }^{23}$ In the earlier writings (1991) he saw them as part and parcel of what he calls 'right wing religion' ${ }^{24}$ He portrays these churches as being either complicit or convenient in the development of corruption and dictatorship in some African countries. ${ }^{25} \mathrm{He}$ also tends to see them as an extension of American imperialism and even as a significant globalising factor. ${ }^{26}$ This paper concurs with Gifford (1991) that Pentecostalism can be controversial and ambiguous at times. This view is based on some Pentecostal churches' attitude towards HIV and AIDS that God heals HIV, and that those members who are HIV positive, must not take ARVs. 


\section{Pentecostal churches in the midst of HIVIAIDS in Botswana}

Lately, foreign Pentecostal pastors in Botswana have been attracting negative attention and making headlines in newspapers, as they were declared prohibited immigrants. Cross-border pastors from churches such as Christ Embassy, Abundant Life Ministries and New Seasons Ministries have been deported from Botswana in recent years. ${ }^{27}$ The reasons for their deportation range from embezzling church funds to discouraging members from taking ARVs. ${ }^{28}$ For example, newspaper reports on the much publicised deportation of Edmore Chaka, the pastor of Abundant Life Ministries, claim that he was deported from Botswana because he taught his followers that God heals HIV and AIDS and therefore instructed them not to take ARVs. ${ }^{29}$ The report alleges that Chaka demanded his Batswana followers to collect the ARVs from clinics and give them to him. His teachings were problematic because it is now a known fact that ARVs prolong life. Further, his teachings contradicted the Botswana health policy which stresses adherence to ARVs. His instruction that his church followers must take the ARVs from hospitals and hand them over to him was controversial and suspicious. It is not certain what he wanted to do with the ARVs and perhaps that is why there was speculation from the community and media houses that he wanted to sell them on the black market. ${ }^{30}$ Whatever his motives, his instruction to his followers to hand the ARVs to him, after he had instructed them not to take medication, remains problematic and controversial. Chaka is not an exception in his teaching and his controversial behaviour, as research from Botswana demonstrates that there are many Pentecostal pastors who advance this kind of teaching and behaviour. ${ }^{31}$ After conducting research to determine the attitudes of Pentecostal Christians towards HIV in Botswana, Togarasei (2010) concludes that there are many Pentecostal Christians who still adopt this position. ${ }^{32}$ Togarasei (2010) demonstrates that the teaching that God cures HIV represents the view held by some African Pentecostal Christians foreign or local since HIV became a reality in the late 1980s. Further, his research demonstrates that most Christians believe that HIV infection is a result of sexual immorality, and therefore a punishment from God. Although the author concurs with Togarasei's (2010) conclusion, it must be pointed out that not all Pentecostal Christians (migrants or locals) hold this perception today, as demonstrated by research participants in a study conducted among Pentecostals mentioned above (Gabaitse 2013). There are some who accept that HIV is not a result of deviant behaviour and that it is not a punishment from God..$^{33}$ This attitude change came about because the Botswana government health sector and other stakeholders have since embarked on an aggressive mission to educate people about the transmission, diagnosis and treatment of HIV-related infections. These campaigns were accompanied by teaching communities about how adherence to treatment can prolong and improve the quality of an HIV-infected life. There have been other campaigns to educate communities about other dynamics of HIV response, such as eating well and keeping a healthy lifestyle when a person is living with HIV. 
Despite these significant campaigns, some of which were intended to destigmatise HIV, there are still some Pentecostal pastors and Christians who think that $\mathrm{HIV}$ is a consequence of sexual sin, as indicated above. This attitude has contributed to a theology of healing which claims that God heals HIV through faith and repentance, therefore, members are told to stop using ARVs so that God can heal them. Just recently, the coordinator of the Selebi-Phikwe District AIDS Committee, Lamech Myengwa, was on record that there are pastors who discourage their members from taking ARVs. ${ }^{34} \mathrm{He}$ said this after a batch of ARVs was found dumped at the BCL mines and there was an indication that the drugs had been collected from different people at the same time and thrown away. According to Myengwa (Mmegi online 2013), people discontinue the use of ARVs because of their religious conviction that taking ARV clashes with God's ability to heal human beings. Similarly, Togarasei (2010) argues that those Pentecostal Christians who discourage the use of ARVs perceive them as a 'manifestation and a contradiction of God's healing powers'. ${ }^{35}$ This is confirmed by Myengwa (Mmegi online 2013), who says that HIV-positive people are instructed to first give up the use of ARVs as a demonstration of their faith in God and as a way to unlock their healing. ${ }^{36}$

The theology that God heals HIV (inadequate, dangerous and flawed as it may be), provides a response towards HIV resulting from the fact that the Botswana health system fails to provide ARVs to cross-border migrants. The theology gives migrants living with HIV (but who cannot access HIV treatment) some hope in a rather hopeless situation. Perhaps it is false hope and some people know it is false hope, but for migrants who have nothing to hold on to, this theology gives them hope. Research indicates that lack of hope can accelerate ill-health. ${ }^{37}$ If understood in this framework of hopelessness, perhaps we can accept that the Pentecostal Church is trying to be relevant to the needs of HIV-positive migrants. It is offering a response where there is no any other life-giving response. However, the theology should be treated with suspicion, in light of the whole Pentecostal theology of health and wealth. Some Pentecostal pastors in Botswana are reported to manipulate people into selling their homes and giving their pension money to them using the health and wealth gospel, which claims that God desires to bestow Pentecostal Christians with blessings and all they need to do is to show that they have faith in God by giving the pastors large sums of money or property to unlock their blessings. ${ }^{38}$ Some cross-border migrant pastors have been accused of engaging in shady, fraudulent activities like money laundering, tax evasion and drug trafficking, and they use the church as a cover up. ${ }^{39}$ It is possible that this theology that God cures HIV might be a well-planned strategy, a cover up and a mask to attract cross-border migrants who find themselves in a desperate situation. It is suspicious that a Pentecostal pastor like Chaka instructs his members not to adhere to HIV treatment, yet he also instructs them to hand the ARVs over to him and nobody knows what he does with them. Perhaps, the theology of healing has little to do with a genuine belief in God's ability to cure HIV and more to do with covering up the sale of ARVs on a black 
market, as suggested above. If this is true, then the theology might be meant for the consumption of migrants who are unaware and unsuspicious of some of these dynamics. Myengwa (Mmegi online 2013), the AIDS coordinator quoted above, confirmed that there are some people who have died while others have developed resistance towards ARVs because they discontinued taking ARVs after their pastors told them to do so..$^{40}$ Members of churches look up to their pastors for guidance and for some, what the pastor says is uncritically believed and practised to the point of death. Because of their ecclesiastical positions, they have the ability to produce and construct life-giving and/or life-denying beliefs and practices among their followers. The irony then is that the Pentecostal Church in its pursuit to present God as the giver of life, fails to preserve that very life. At the core of Pentecostal Christian living is the dignity of a person and the pursuit of life in abundance, and the evidence presented here suggests that the Pentecostal Church has failed to uplift that dignity and life of HIV-positive cross-border migrants.

The theology that God heals is not necessarily a bad theology. There is a strong belief among Africans that God heals sick people; even as they take medication, it is still God who heals, not the medication. ${ }^{41}$ In this belief, complete recovery of a sick person is never due to medication, but to the healing powers of God. The primary challenge with the Pentecostal theology of God healing HIV lies in the emphasis that members must stop taking ARVs because taking them is synonymous to lack of faith in the healing powers of God. The other challenge with this theology in the context of Botswana is that it often leads to conflict between the Pentecostal churches and the government policy on adherence to HIV treatment. The conflict between Pentecostal churches and government is obvious because the central message of HIV treatment in Botswana stresses prevention and adherence to treatment.

\section{Botswana HIVIAIDS policies and migrants}

Botswana has made significant progress in the fight against HIV/AIDS, mainly in the areas of HIV awareness, testing and treatment. There are testing centres all over the country, and most importantly ARVs are free for locals. However, the country has failed in the global fight against HIV because Botswana policy on HIV/AIDS is not progressive towards cross-border migrants, who are denied access to ARVs. The government of Botswana maintains that providing ARVs to cross-border migrants living in Botswana is expensive. ${ }^{42}$ As a result, migrants who are HIV positive have to purchase ARVs from private clinics at exorbitant prices. ${ }^{43}$ Unfortunately, only the minority working middle to high class cross-border migrants who are members of medical aid schemes can afford to buy ARVs. The majority of the crossborder migrants, some of whom are in the country illegally and without proper documentation, cannot afford to buy them.

For a long time, Uyapo Ndadi, the director and lawyer at Botswana Network on Ethics, Law and HIV/AIDS, (BONELA) has been fighting to 'force' the government 
of Botswana to provide ARVs to foreign nationals, especially those in prisons. ${ }^{44}$ Ndadi has argued in courts that there are many cross-border inmates who are living with HIV, some with low CD4 counts and already presenting with opportunistic infections. He says some of them even have full blown AIDS and still the treatment was withheld from them. Ndadi's submission is that incarcerated inmates living with HIV do not have the opportunity to buy ARVs in private clinics and hospitals, even if they had the money. Failure to treat migrant inmates endangers other inmates, both migrants and citizens. This is because research demonstrates that prisons are high risk environments for the transmission and spread of HIV and therefore HIV prevalence is high in prisons. ${ }^{45}$

Locally, this is confirmed by the director of Botswana Institute of Rehabilitation and Reintegration of Offenders (BIRRO) who has stated that in Botswana there are inmates who contract the virus when they are in prison. ${ }^{46}$ This information suggests that sexual intercourse happens among inmates even in Botswana. Although, there are many ways of contracting the virus, HIV is mainly transmitted through sex. Considering that the Botswana government is against condom distribution in prisons, this makes inmates more susceptible to contracting HIV. Not only are inmates at risk, but their partners are at risk following their release from prison. This is because they may not even be aware of their status or they may not disclose it to their partners.

The Botswana policy of denying cross-border migrants HIV treatment raises concerns about justice, human rights and the role of Botswana in combating the spread of HIV at the global level. At the 2006 United Nations General Assembly high level meeting, ${ }^{47}$ member states, of which Botswana is one, agreed to work towards the goal of achieving universal access to comprehensive HIV/AIDS programmes, treatment and care by 2010 . Member states committed themselves to promoting HIV/AIDS education, information, voluntary counselling, testing and treatment at international, regional, national and local levels. This goal of achieving universal access to comprehensive HIV/AIDS programmes means that all people, regardless of race, gender, ethnicity and nationality, are entitled to access HIV services wherever they are. One of the basic requirements for achieving this goal is for testing services to be made available to all people so that at the very least they should know their HIV status. This basic requirement remains unattainable for crossborder migrants, although there are free testing centres throughout most towns and villages in Botswana.

In March 2010 the Global Fund awarded SADC member states a grant that could be used to improve regional responses to HIV/AIDS among mobile populations (long distance truck drivers, commercial sex workers and people living close to crossborder sites).$^{48}$ The goal of this initiative was to reduce HIV infection and to mitigate the impact that HIV has on mobile populations across the SADC region. Botswana signed the memorandum of agreement with the Global Fund in July 2012. ${ }^{49}$ The country was supposed to set up mobile clinics at border posts such as Tlokweng, so that mobile populations can access at least some of the basic HIV services such 
as testing and screening. ${ }^{50}$ The report concludes that as at 2012, those mobile sites had not been established and there were no services, interventions and attempts that focus on providing HIV services to cross-border migrants, despite the fact that their vulnerability to HIV infection is high. ${ }^{51}$ There is no initiative from within the health sector that focuses on cross-border migrants and the basic issues concerning HIV such as healthy living and avoiding infection or reinfection. According to the UN declaration on human rights, access to health services is a right for all. Therefore, if understood within this framework of universal human rights, denying cross-border migrants access to ARVs is an infringement on their right to health and this raises questions about justice and dignity. Furthermore, denying them access to ARVs is also an infringement on their right to life. Unfortunately, the government of Botswana has not agreed to offer HIV services to cross-border migrants, yet the sad reality is that both migrant and host populations are at an increased risk of HIV infection.

It then follows that denying cross-border migrants access to ARVs is selfdefeating for the government of Botswana and it has dire consequences as far as HIV infection is concerned. This is as a result of two main factors. First, epidemiological studies have established a clear relationship between migration and the spread of communicable diseases. ${ }^{52}$ Communicable diseases like bird flu and Ebola spread through migration. There is no questioning the fact that there are linkages between the spread of HIV/AIDS and migration, as demonstrated above. Second, it is obvious that sexual relations and contact, whether forced or consensual, take place between cross-border migrants and the host populations. Some migrants and locals even enter into genuine relationships that result in long-term relationships such as marriages. Prison inmates, both migrants and locals, have sexual relations. Some migrants, especially women, may seek sexual partnerships of convenience with locals in search of social support and economic survival. These factors expose both migrants and host populations to HIV infections. Thus through sexual networks, temporary, short or long-term, HIV is spread within and among communities of migrants and host populations. This article therefore upholds the view that no fight for an HIV free Botswana can be successful without providing HIV services and ARVs to crossborder migrants.

It is argued that a holistic response to containing the spread of HIV necessarily requires that at least the basic HIV services like education should be availed to crossborder migrants. It is imperative that the Botswana government acknowledge the connection between migration and HIV/AIDS so that HIV treatment is availed to cross-border migrants. Failure to do this poses a serious challenge to the success of combating the spread of HIV and it is unlikely that the greater struggle to contain the HIV infections and reduce AIDS related deaths, can be won locally. This may represent a regression in trying to curb HIV-related deaths in the near future. Further, this hinders not only SADC's efforts of mitigating the impacts of HIV and AIDS, but the global fight for the eradication of the virus. Thus this health policy and the 
Pentecostal churches' theology of HIV become serious partners in a crime against migrants, as argued below.

\section{The Pentecostal Church and Botswana HIV policy: Partners in crime}

The fact that there is tension between the government of Botswana and some Pentecostal pastors who claim that God heals HIV is ironic and paradoxical. It is ironic because both systems are in agreement that cross-border migrants should not have access to ARVs. Further, it is paradoxical in that both systems are supposed to be saving lives, and yet they are taking away that very life.

Ambiguity exists in that there is a clear acknowledgement that without ARVs, HIV-positive people (regardless of race and nationality) ultimately die due to opportunistic infections. But, the only people the Botswana HIV policy seeks to protect from dying, are the citizens of Botswana. Furthermore, some Pentecostal crossborder migrants may want to take ARVs in spite of the theology of their churches, but the challenge they face is that ARVs are not available to them. Therefore, they are driven into desperation to stay within the Pentecostal space where they are given some hope to hold on to. That hope does not exist as far as the Botswana HIV policy is concerned. If HIV services were made available to migrants, the government of Botswana could protect them from pastors who claim that they can heal HIV. One of the ways of doing that could be to offer them the opportunity to re-test after prayers for healing have taken place. Chances are if they tested positive for HIV antibodies the first time, they would test positive even after prayers of healing have taken place. In this way the theology might not be attractive to migrants in need of a response towards HIV, because church members will know that it is not effective. Furthermore, ambiguity exists in that the Pentecostal theology of non-adherence to HIV treatment stands in ironic opposition to the Botswana policy on strict adherence to ARVs, yet at the core, both deny cross-border migrants access to ARVs and therefore, the right to life. This makes them partners in crime.

\section{Way forward}

The Pentecostal theology and government of Botswana HIV policy on migrants as discussed above, both need rethinking. One of the ways in which the Pentecostal Church can move away from teaching non-adherence towards ARVs is to develop a new theology to replace this one which is inadequate and flawed. Togarasei (2010) suggests this when he offers what he terms a 'Theology of ARVs. ${ }^{53} \mathrm{He}$ argues that since some of these Pentecostal pastors use the Bible to argue for an anti-ARV theology, the same Bible could be used to offer an alternative theology which will encourage the use of ARVs. He suggests two principles that should guide this 
theology. The first principle has to do with the sanctity of life, which is a fundamental principle among all Pentecostals. He argues that ARVs should be understood in the framework of preserving life when it is 'threatened by evil'. ${ }^{54}$ They should be seen as protecting and giving back life to people living with HIV; who almost lost it due to HIV-related illnesses. The second principle that he suggests is that 'scientific discoveries that enhance human life should be seen as God-sanctioned. This way ARVs should be seen not as competing with God's power but as manifestation of God's power' ${ }^{55}$ Both principles foreground the sanctity and sacredness of human life, which must necessarily guide all Christian theologies, Pentecostal or other. Therefore, the Pentecostal Church should be intentional about encouraging the use of ARVs because it is a fact that they do preserve life and the dignity of people who would otherwise die.

The second way in which the Pentecostal Church could move away from teaching non-adherence to ARVs, is to develop a critical reading of the Bible. Using the Bible, a comprehensive teaching of healing must be developed. The teaching should demonstrate that sickness is suffering, yet God desires a life for God's person that is free from suffering. Since ARVs alleviate physical body suffering, they will be appreciated as God-given. Only if HIV \AIDS is understood within the larger framework of life, health and suffering, then, instead of teaching non-adherence to ARVs, the Pentecostal churches could be a catalyst for transformation in lobbying the Botswana government for migrants' access to ARVs on the basis that the very gift of life that God has given to all human beings, is destroyed if migrants are denied access to ARVs.

Similarly, the Botswana government can benefit from foregrounding the universal human right to life. It is true that ARVs are expensive, but the life of a person, migrant or not, is far more expensive and sacred. Botswana accedes to the UN declaration on human rights for all and the country has committed itself to the 2006 United Nations General Assembly's goal of achieving universal access to comprehensive HIV/AIDS programmes, treatment and care by 2010. Furthermore, there are other SADC initiatives on reducing HIV infection rates to which Botswana is a signatory. All these instruments which are intended to help countries develop policies that make the preservation of human life central, should be underlined in persuading the Botswana government to change its policy.

\section{Conclusion}

Cross-border migrants living in Botswana inhabit spaces where the quality of their life is diminished by the Botswana laws and policies on HIV and by the Pentecostal Church's theology of healing. Both these systems intersect in denying them access to ARVs and to quality health care and ultimately deny them the very gift of life. Both institutions need to respond meaningfully to the rights of the cross-border migrants to health services. Furthermore, they must be committed to protecting the life and 
dignity of cross-border migrants. As it is, the responses of both systems violate the universal, fundamental and basic right to life and access to health care for all people regardless of their nationality. This paper demonstrates that the tension which exists between the two is ironic because at the core, both intersect in denying cross-border migrants life. The situation could change only if both systems make the preservation and saving of life their core business in terms of theology for the Pentecostal Church and the policy for Botswana's health care system. It should not matter whose life it is that is foregrounded, because everyone has the right to life and health care. After all, both systems are supposed to be in the 'business' of saving and preserving lives. It is only when Pentecostal churches advocate for migrants' right to anti-retroviral treatment that they can truly be a 'home away from home' for migrants.

\section{ENDNOTES}

1. Reitzes, M. 1997. 'The migrant challenge to Realpolitik: Towards a human rights-based approach to immigration policy in South and southern Africa.' Johannesburg: Foundation for Global Dialogue, Occasional Paper.

2. Banda, I. (n.d.) Zimbabwe: Children crossing borders in search of HIV treatment http://allafrica.com/stories/201008240798.html (accessed July 28 2014).

3. Crush, J., V. Williams and S. Peberdy. 2005. Migration in southern Africa. Geneva: Global Commission on International Migration, pp. 5, 10, 24

4. Johnson T.M. and G. Zurlo. 2012. 'Migration, religious diasporas, and religious diversity: A global survey,' Mission Studies 29, pp. 3-22: Frieder, L. and J. Kwabena Asamoah-Gyadu eds. 2011. The African Christian presence in the West: New immigrant congregations and transnational networks in North America and Europe. Trenton: Africa World Press; Wild-Wood, E. 2008. 'Migration and Christian identity in Congo (DRC),' Studies of Religion in Africa 35. Leiden: Brill..

5. Anderson, A. 1999. 'World Pentecostalism at a crossroads.' In Pentecostals after a century: Global perspectives on a movement in transition, eds, A. Anderson and W.J. Hollenweger. Sheffield Academic Press, p. 19.

6. Asamoah-Gyadu, K. 2005. African charismatics: Current developments within independent indigenous Pentecostalism in Ghana. Leiden: Brill, p. 1-2; Kwame, B. 1995. Christianity in Africa: The renewal of a non-Western religion. Maryknoll: Orbis, pp. 4-5.

7. Omenyo, C.N. 2006. 'Pentecost outside Penetecostalism: A study of the development of charismatic renewal in the mainline churches in Ghana, ' Uitgeverij Boekencentrum.

8. See for example Anderson, A.1999. 'Introduction: World Pentecostalism at a crossroads.' In Pentecostals after a century: Global perspectives on a movement in transition, eds, A. Anderson and W. Hollenweger. Sheffield Academic Press, p. 9.

9. Hanciles, J.J. 2009. Globalization, African migration and the transformation of the West. Maryknoll: Orbis Books, p. 76. 
10. Asamoah-Gyadu, J.K. 2005. African charismatics: Current developments within independent indigenous Pentecostalism in Ghana. Leiden: Brill Academic Publishers, p. 8 .

11. Olivier, M. 2011. 'Enhancing access to South African social security benefits by SADC citizens: The need to improve bilateral arrangements within a multilateral framework. (Part I), SADC Law Journal, Vol. 1, 2011 http://www.sadclawjournal.org/index. php? module $=$ Content $\% 20$ editing \& func $=$ view\&pid=21; Barnard, A. et al. 2005. 'Gag on free speech casts a shadow on Africa's "Beacon of Democracy".' Letters to the Editor, The Scotsman, 24 February.

12. Olivier, M. 2011. 'Enhancing access to South African social security benefits by SADC citizens: The need to improve bilateral arrangements within a multilateral framework. (Part I), SADC Law Journal, Vol. 1, 2011.

13. Chirongoma, S. 2006. 'Women, poverty and HIV in Zimbabwe: An exploration of inequalities in health care.' In African women, religion, and health: Essays in honor of mercy. Amba Ewudziwa Oduyoye eds. Isabel Apawo Phiri and Sarojini Nadar. Maryknoll: Orbis.

14. Stepanek, M. and J. Skorpik. 2005. 'Social security in a long life society.' Unpublished paper presented at the Fourth International Social Security Association (ISSA) International Research Conference on Social Security, Antwerp, 5-7 May 2005, p. 3. See also Olivier, M. 2011. 'Enhancing access to South African social security benefits by SADC citizens: The need to improve bilateral arrangements within a multilateral framework. (Part I), SADC Law Journal, Vol. 1, 2011. This is not in any way suggesting that all cross-border migrants come from countries that are politically unstable, there are some who migrated to Botswana because they wanted to work and stay in Botswana.

15. Bible Life Ministries is one of the largest Pentecostal churches in Botswana founded by a Malawian national, Enock Setima.

16. Waller, L. 2006. 'Irregular migration to South Africa during the first ten years of democracy.' SAMP Migration Policy Brief No. 19. Kingston/Cape Town: Southern African Migration Project.

17. Ter Haar, G. 1998. Halfway to paradise: African Christians in Europe. Wales: Cardiff Academic Press.

18. Landau, L.B. ed. 2011. Exorcising the demons within: Xenophobia, violence and statecraft in contemporary South Africa. Johannesburg: Wits University Press.

19. Ter Haar, G. 1998. Halfway to paradise: African Christians in Europe. Wales: Cardiff Academic Press, p. 49.

20. Johnson, T.M. and G. Zurlo. 2012. 'Migration, religious diasporas, and religious diversity: A global survey,' Mission Studies, 29, pp. 3-22.

21. The author carried out research on modes of reading among Pentecostals from 2011 to 2012. One of the methods used was participant observation among other methods, which are described in detail in the author's thesis. Out of this research context the author was able to glean information or observed a range of themes such as styles of 
praise and worship, violence against women, migration, methods of healing and gender relations, etc. See Gabaitse, R.M. 2013. Towards an African Pentecostal feminist Biblical hermeneutic of liberation: A case study of interpreting Luke-Acts with Batswana women. Unpublished $\mathrm{PhD}$ thesis, University of KwaZulu Natal, Pietermaritzburg.

22. Gabaitse, R. 2013. 'Towards an African Pentecostal feminist Biblical hermeneutic of liberation: Interpreting Luke-Acts with Batswana women.' Unpublished $\mathrm{PhD}$ thesis, University of KwaZulu-Natal, Pietermaritzburg.

23. Gifford, P. 2004. Ghana's new Christianity: Pentecostalism in a globalizing African economy. Bloomington: Indiana University Press.

24. Gifford, P. 1991. The new crusader: Christianity and the new right in Southern Africa. Pluto: London and Concordia, MA, p. 96. See also Coleman, S. 2000. The globalisation of charismatic Christianity. Cambridge University Press, pp. 25-26.

25. Gifford, P. 1998. African Christianity: Its public role. London: Hurst.

26. Gifford, P. 1993. Christianity and politics in Doe's Liberia. Cambridge University Press, pp. 196-199; idem, African Christianity, pp. 315-317; idem 'Christian Fundamentalism and development in Africa', Review of African Political Economy, Vol. 52(1991): 9-20. See also, Martin, D. 2002. Pentecostalism: The World Thier Parish. Massachusetts: Blackwell Publishers, p. 137.

27. Mmegi. The Monitor 2008, 'Christ Embassy Pastor Deported'. Vol. 21: 116, 11, August 2008.

28. Mmegi. The Monitor 2008, 'Christ Embassy Pastor Deported'.

29. Mmegi. The Monitor 2008, 'Christ Embassy Pastor Deported': Sunday Standard online edition, 'Abundant Ministries Church feared to be a cover for ARV drugs racket'http:// www.sundaystandard.info/article.php?NewsID=3578\&GroupID=1 (accessed July 2014).

30. Sunday Standard online edition 'Abundant Ministries Church feared to be a cover for ARV drugs racket' http://www.sundaystandard.info/article.php?NewsID=3578\&GroupID=1 (accessed July 2014).

31. Togarasei, L. 2010. 'Christian theology of life, death and healing in an era of antiretroviral therapy: Reflections on the responses of some Botswana churches.' African Journal of AIDS Research Vol. 9(4): 429.

32. Togarasei, L. 2010. 'Christian theology of life, death and healing...' p. 429.

33. There is a governing body for Pentecostal churches called Evangelical Fellowship of Botswana (EFB). Different Pentecostal churches can become members of this body if they so wish. The EFB's official position is that Pentecostal members who are HIV positive should take ARVs. The organisation has an HIV desk which tries to engage willing churches on issues such as adherence to treatment. However, the official position of EFB does not necessarily translate into the theology that individual Pentecostal pastors teach.

34. Mmegi online. 2013. 'AIDS Coordinator accuses pastors of discouraging ARV intake,' Vol. 30(36), 8 March. 
35. Togarasei, L. 2010. 'Christian theology of life, death and healing in an era of antiretroviral therapy: Reflections on the responses of some Botswana churches.' African Journal of AIDS Research Vol. 9(4): 429-435.

36. Mmegi online. 2013. 'AIDS coordinator accuses pastors of discouraging ARV intake'.

37. Gould, E. 2008. Secrets of cancer survivors: A book of hope for cancer patients, their families and friends. Melbourne: Michelle Anderson Publishing.

38. Mmegi online. 2012a. 'Why Sakufiwa was deported.' Vol. 29(79), 30 May; Mmegi online. 2012b, 'Selling God to the highest bidder'. Vol. 29(81), 01 June.

39. Mmegi online. 2012a. 'Why Sakufiwa was deported.' Vol. 29(79), 30 May 2012; Mmegi online. 2012b. 'Selling God to the highest bidder'. Vol. 29(81), Friday, 01 June.

40. Although the theology that God cures HIV is inadequate and flawed, it cannot be denied that there are other Pentecostal pastors, who through an uncritical reading of the Bible, genuinely believe that God cures HIV and AIDS. These are the pastors who can be helped by offering them a comprehensive and alternative understanding of healing that stresses that God heals through faith and medical interventions. Sometimes, especially in high context cultures like Botswana, some pastors may genuinely not be aware that ARVs are effective because they do not have access to information or they may not read the Bible comprehensively and critically.

41. Appiah-Kubi, K. 1981. Man cures, God heals: Religion and medical practice among the Akans of Ghana Allanheld: Osmun.

42. Malema, B.K.W and S.F. Koch. 2008. 'The free provision of ARV therapy: Is it a golden opportunity on a silver platter for organisations?' BOJE: Botswana Journal of Economics Vol. 5(7), October, 2008, pp. 84-92.

43. Malema, B.K.W and S.F. Koch. 2008. 'The free provision of ARV therapy: Is it a golden opportunity on a silver platter for organisations?' BOJE: Botswana Journal of Economics Vol. 5(7), October, 2008, pp. 84-92.

44. Tebogo, T. 2013. 'BONELA, inmates intend law suit.' BOPA July, 2013.

45. Prisons and AIDS. UNAIDS report 1997 http://data.unaids.org/Publications/IRC-pub05/ prisons-pov_en.pdf.

46. Sunday Standard online edition, 2012. 'BONELA and former offenders at odds over condom distribution,' October 2012.

47. UNAIDS Resolution adopted by the General Assembly: Political Declaration on HIV and AIDS http://data.unaids.org/pub/Report/2006/20060615_hlm_politicaldeclaration_ ares60262_en.pdf (accessed July 2013).

48. SADC HIV and AIDS Cross-border Initiative: A Global Fund Project http://www. k4health.org/sites/default/files/SADC_Cross_Border_Initiative_2012. The information can also be found at https://www.k4health.org/sites/default/files/SADC_Regional_ Collaboration_TB_2012.pdf.

49. SADC HIV and AIDS Cross-border Initiative: A Global Fund Project https://www. k4health.org/sites/default/files/SADC_Regional_Collaboration_TB_2012.pdf.

50. The initiative seems to be focused on those who enter the country legally. The challenge 
is that most cross-border migrants enter the country illegally and these will not be catered for by this initiative.

51. No such structures have been established even as late as 2014 .

52. Callahan, B.T and V. Bond. 1999. 'The social, cultural and epidemiological history of sexually transmitted diseases in Zambia.' In P. Setel,, M. Lewis and M. Lyons eds. 1999. Histories of sexually transmitted diseases and HIV/AIDS in sub-Saharan Africa. Westport: Green Wood Press.

53. Togarasei, L. 2010. 'Christian theology of life, death and healing in an era of antiretroviral therapy: Reflections on the responses of some Botswana churches.' African Journal of AIDS Research Vol. 9(4): 433.

54. Togarasei, L. 2010. 'Christian theology of life...' p. 433.

55. Togarasei, L. 2010. 'Christian theology of life...' p. 433.

\section{LIST OF REFERENCES}

Anderson, A. 1999. 'World Pentecostalism at a crossroads.' In Pentecostals after a century: Global perspectives on a movement in transition, eds. A. Anderson and W.J. Hollenweger. Sheffield Academic Press.

Appiah-Kubi, K. 1981. Man cures, God heals: Religion and medical practice among the Akans of Ghana Allanheld: Osmun.

Asamoah-Gyadu, K. 2005. African charismatics: Current developments within independent indigenous Pentecostalism in Ghana. Leiden: Brill.

Banda, I. (n.d.) Zimbabwe: Children crossing borders in search of HIV treatment http://allafrica. com/stories/201008240798.html (accessed July 28 2014).

Barnard, A. et al. 2005. 'Gag on free speech casts a shadow on Africa's "Beacon of Democracy",' Letters to the Editor, The Scotsman, 24 February.

Malema, B.K.W. and S.F. Koch. 2008. 'The free provision of ARV therapy: Is it a golden opportunity on a silver platter for organisations?' BOJE: Botswana Journal of Economics Vol. 5(7), October, 2008, pp. 84-92.

Callahan, B.T. and V. Bond. 1999. 'The social, cultural and epidemiological history of sexually transmitted diseases in Zambia.' In Histories of sexually transmitted diseases and HIVIAIDS in sub-Saharan Africa, P. Setel, M. Lewis and M. Lyons. Westport: Green Wood Press.

Chirongoma, S. 2006. 'Women, poverty and HIV in Zimbabwe: An exploration of inequalities in health care.' In African women, religion, and health: Essays in honor of mercy. Amba Ewudziwa Oduyoye eds. Isabel Apawo Phiri and Sarojini Nadar. Maryknoll: Orbis.

Coleman, S. 2000. The globalisation of charismatic Christianity. Cambridge University Press.

Crush, J., V. Williams and S. Peberdy. 2005. Migration in Southern Africa. Geneva: Global Commission on International Migration, pp. 5, 10, 24.

Frieder, L. and J. Kwabena Asamoah-Gyadu eds. 2011. The African Christian presence in the West: New immigrant congregations and transnational networks in North America and Europe. Trenton: Africa World Press. 
Gabaitse, R.M. 2013. Towards an African Pentecostal feminist Biblical hermeneutic of liberation: A case study of interpreting Luke-Acts with Batswana Women. Unpublished PhD thesis, University of KwaZulu Natal, Pietermaritzburg.

Gifford, P. 1991. The new crusader: Christianity and the new right in southern Africa. London and Concordia: Pluto.

Gifford, P. 1993. Christianity and politics in Doe's Liberia. Cambridge University Press.

Gifford, P. 1998: African Christianity: Its public role. London: Hurst.

Gifford, P. 2004. Ghana's new Christianity: Pentecostalism in a globalizing African economy. Bloomington: Indiana University Press.

Gould, E. 2008. Secrets of cancer survivors: A book of hope for cancer patients, their families and friends. Melbourne: Michelle Anderson Publishing.

Hanciles, J. 2009. 'African Christianity, globalization, and mission: Marginalizing the center.' In Interpreting contemporary Christianity: Global processes and local identities, eds. O.U. Kalu and A. Low. Michigan: William Eerdmans, pp. 71-90.

Johnson, T.M. and G.A. Bellofatto. 2012. 'Migration, religious diasporas, and religious diversity: A global survey.' Mission Studies 29: 3-22.

Johnson T.M. and G. Zurlo. 2012. 'Migration, religious diasporas, and religious diversity: A global survey,' Mission Studies 29, pp. 3-22.

Kwame, B. 1995. Christianity in Africa: The renewal of a non-Western religion. Maryknoll: Orbis.

Landau, L.B. ed. 2011. Exorcising the demons within: Xenophobia, violence and statecraft in contemporary South Africa. Johannesburg: Wits University Press.

Martin, D. 2002. Pentecostalism: The world their parish. Massachusetts: Blackwell Publishers.

Mmegi: The Monitor. 2008. 'Christ Embassy Pastor deported,' Vol. 21: 116, 11 August.

Mmegi online. 2012a. 'Why Sakufiwa was deported,' Vol. 29(79), 30 May.

Mmegi online. 2012b. 'Selling God to the highest bidder,' Vol. 29(81), Friday, 01 June.

Mmegi online. 2013. 'AIDS coordinator accuses pastors of discouraging ARV intake,' Vol. 30(36), 8 March.

Olivier, M. 2011. 'Enhancing access to South African social security benefits by SADC citizens: The need to improve bilateral arrangements within a multilateral framework. (Part I) SADC Law Journal, Vol. 1, 2011 http://www.sadclawjournal.org/index.php?module=Content $\% 20$ editing\& func $=$ view $\&$ pid $=21$.

Omenyo, C.N. 2006. 'Pentecost outside Penetecostalism: A study of the development of charismatic renewal in the mainline churches in Ghana'. Uitgeverij Boekencentrum.

Reitzes, M. 1997. The migrant challenge to Realpolitik: Towards a human rights-based approach to immigration policy in South and southern Africa. Johannesburg: Foundation for Global Dialogue, Occasional Paper.

SADC HIV and AIDS Cross-border Initiative: A Global Fund Project http://www.k4health.org/ sites/default/files/SADC_Cross_Border_Initiative_2012. The information can also be found at https://www.k4health.org/sites/default/files/SADC_Regional_Collaboration_TB_2012. pdf.

Stepanek, M. and J. Skorpik. 2005. 'Social security in a long life society.' Unpublished paper presented at the Fourth International Social Security Association (ISSA) International Research Conference on Social Security, Antwerp, 5-7 May 2005, p. 3. 
Sunday Standard, 22-10-2012 http://www.k4health.org/sites/default/files/SADC_Cross_Border_ Initiative 2012.

Sunday Standard online edition, 2012. 'BONELA and former offenders at odds over condom distribution'. October 2012.

Tebogo, T. 2013. 'BONELA, inmates intend law suit.' BOPA July, 2013.

Ter Haar, G. 1998. Halfway to paradise: African Christians in Europe. Wales: Cardiff Academic Press.

The Monitor 11 August 2008 Vol. 21: 116 http://www.unaids.org/en/resources/documents/1997/.

Togarasei, L. 2010. 'Christian theology of life, death and healing in an era of antiretroviral therapy: reflections on the responses of some Botswana churches,' African Journal of AIDS Research, Vol. 9(4): 429.

UNAIDS Resolution adopted by the General Assembly: Political Declaration on HIV and AIDS http://data.unaids.org/pub/Report/2006/20060615_hlm_politicaldeclaration_ares60262_ en.pdf (accessed July 2013).

Waller, L. 2006. 'Irregular migration to South Africa during the first ten years of democracy.' SAMP Migration Policy Brief No. 19. Kingston/Cape Town: Southern African Migration Project.

Wild-Wood, E. 2008. 'Migration and Christian identity in Congo (DRC),' Studies of Religion in Africa, 35. Leiden: Brill. 